\title{
Skrammer i de baltiske succeshistorier
}

\section{Ib Alken}

\section{Efter fem fede år med kreditfinansierede nye biler og boliger har finanskrisen sat punktum for for- brugsfesten. Det er tid til at rebe ind, men det kræver modige politiske beslutninger}

Hvis nogen i senfirserne havde sagt til folk i en af de baltiske stater, at om 20 år ville selv deres bedste forhåbninger for den politiske fremtid om selvstændighed, økonomisk vækst og vestlig orientering være opfyldt, ville de ikke have troet det muligt. Men sådan blev det så alligevel, uagtet de mange resterende problemer. Da jeg - det var vist i år 2000 klagede til Politikens chefredaktør over, at det var mere end svært at få artikler om landene optaget, sagde Tøger Seidenfaden: "De baltiske lande er jo blevet en succeshistorie, så det har ikke længere den store interesse."

Processen forud var gået hurtigt. Men ikke uden videre glat. De baltiske republikker havde ganske vist ikke Muren som demarkationslinje, men var stadig indlemmet i Sovjetunionen på vilkår, de ikke selv hav- de indflydelse på. Denne tvangsindlemmelse efterlod dybe spor hos alle tre baltiske befolkninger, som var med til at præge udviklingen efter selvstændigheden.

For at give et overblik over perioden 1989 - 2009 gennemgås her de tre republikkers udvikling ud fra nogle få fælles kriterier. Det er forsøgt i det følgende med afsæt i Letland, hvor jeg har boet og arbejdet siden 2000.

De baltiske republikkers gradvise brud med Sovjetunionen har tilfælles, at reformbevægelserne havde folkeligt udspring, var ledet af personer uden for de politiske eliter og gradvist integrerede dele af de nationale kommunistiske partiers medlemmer. Efter fem årtiers fornægtelse af national egenart for at passe dem ind i skabelonen for sovjetmennesket var det naturligt, at de folke- 
lige bevægelser blev stærkt nationalistiske.

De baltiske republikker har fællestræk, som adskiller dem fra andre tidligere sovjetrepublikker og nogle af de central- og østeuropæiske transitionslande. Balterne var under skrappere Moskva-styring end nogen anden del af sovjetimperiet og var afskåret fra kulturelle, økonomiske og politiske kontakter udefra. Estland havde dog fordel af en begrænset, men livskraftig forbindelse til Finland. De holdt alle erindringen om 1920'ernes og 1930'ernes uafhængighed i live, og inspirationen derfra var sammen med inspirationen fra opbrud med kommunismen i Centraleuropa med til at virkeliggøre selvstændigheden.

Men de havde samtidig dilemmaet med etnisk deling. Vægten af det dilemma illustreres af andelen af russere i befolkningerne, som er ganske forskellige - Estland 26 procent, Litauen bare 6 procent, men Letland 41 procent. Hvordan landene har forsøgt at balancere med dette, bliver nærmere skildret i de enkelte landeafsnit.

En fælles skæbne var det, der kaldes 'den dobbelte besættelse'. Først af sovjetiske styrker i sommeren 1940, så af den tyske Wehrmacht i juli 1941, og efter afslutningen på Anden Verdenskrig indlemmelsen i Sovjetstaten, som kom til at vare i 46 år. Det er opfattelsen i det baltiske område, at her endte Anden Verdenskrig først i 1991.
I takt med sovjetstatens svækkelse steg balternes forhåbninger om uafhængighed og måske endda selvstændighed. Det inspirerede til folkelige demonstrationer - 'Den syngende Revolution' -, som i 1987 blev til en menneskekæde fra Tallinn til Vilnius via Riga med over 2 millioner deltagere. Formel uafhængighed og statsdannelse kom først i sensommeren 1991, hvor det mislykkede kup i Moskva skabte et velegnet øjeblik for de tre baltiske republikker.

I de følgende 18 år har de baltiske republikker arbejdet sig gennem tre faser, som falder på lidt forskellige årstal, men har tydelige fælles træk. Efter uafhængigheden skulle skabes et fungerede statsapparat og tages stilling til en række praktiske og formelle spørgsmål, som var ukendte områder for de nye ledelser. Derefter indledtes en lang transitionsperiode, hvor et politisk og økonomisk systemskifte skulle gennemføres og konsolideres. Samtidig med at der skulle tages hensyn til den befolkning, der bar virkeliggørelsen af uafhængigheden, og havde store forventninger om demokrati, retfærdighed og økonomiske forbedringer.

Processen forud for optagelsen i EU i 2004 bidrog til at accellerere den tiltrængte modernisering af administrationen og nyskabelser i lovgivningerne, som var forudsætning for liberalisering og økonomisk ekspansion.

Med EU-medlemskabet fulgte en kraftig økonomisk vækst i alle tre 
baltiske lande, som i nogle år skiftedes til at ligge i spidsen af OECDfamilien med årlige væksttal på 6-9 procent. For Letlands vedkommende blev der tale om en regulær boble, gearet til boligmarkedet og finansieret ved lån udefra. Det samme var tilfældet i Estland med kun lidt mindre alvorlige konsekvenser og i mindre grad i Litauen. Finanskrisen fra efteråret 2008 bragte et brat stop på forbrugsfesten og gjorde det klart for befolkningerne, at prisen for de seneste års nemme penge var en tocifret inflation og gældsætning.

For at vurdere de tre baltiske republikkers udsigter til at komme nogenlunde helskindet ud på den anden side af den økonomiske krise gives i det følgende et øjebliksbillede af hver enkelt republik med en prognose afslutningsvis.

\section{Estlands indenrigspolitik}

Statsoverhovedet er en præsident, valgt med kvalificeret flertal af parlamentet (Riigikogu). Valget træffes af et valgmandskollegium, hvis der ikke er tilstrækkeligt stort flertal i parlamentet. Den siddende præsident, Toomas Hendrik Ilves, tiltrådte i oktober 2006 for en 5-årig periode.

Det seneste parlamentsvalg i marts 2007 førte til dannelsen af en centrum-højre treparti-regering, bestående af det liberale Reformparti, det nationalt-konservative Res Publica-Pro Patria (IRL) og Socialdemokratiet med Andrus Ansip som pre- mierminister. Den 21. maj 2009 sprængtes koalitionsregeringen som følge af uenighed om den økonomiske politik. Reformpartiet og IRL er fortsat som mindretalsregering med Ansip som statsminister. Den sidder på 50 af parlamentets 101 pladser. Regeringen sætter sin lid til, at markedskræfterne og en stram finanspolitik vil bringe Estland ud af den økonomiske recession og tilbage på vækstsporet.

Der bor ca. 329.000 etniske russere i Estland. Heraf har 117.000 estisk statsborgerskab, 96.000 har russisk statsborgerskab og ca. 116.000 er statsløse. Ikke-estere kan opnå statsborgerskab gennem en naturaliseringsproces. Statsløse og russiske statsborgere har stemmeret til lokalvalg, men ikke ved valg til det estiske parlament og Europa-Parlamentet.

Med integrationsprogrammet for 2008-2013 har regeringen lagt op til en langt mere offensiv tilgang til integrationen med intensivering af undervisningen på estisk på de fortsat mange russiske skoler og gymnasier og for offentligt ansatte. Hertil kommer støtte til kulturelle foreninger, organisationer for etniske minoriteter og søndagsskoleprojekter.

\section{Estisk økonomi}

Den estiske økonomi var i en årrække frem til 2008 præget af høje vækstrater, faldende arbejdsløshed og kraftig lønvækst. Denne positive ud- 
vikling placerede Estlands per capita BNP på 67 procent af EU-gennemsnittet. Blandt de midler regeringen har taget til hjælp for at fremme og fastholde vækst er lav og faldende indkomstskat, som fra 25 procent $\mathrm{i}$ 1994 vil være 18 procent i 2010 uafhængig af indkomstens størrelse.

Fra efteråret 2008 ramte den internationale finanskrise også Estland i form af økonomisk recession, stigende ledighed, faldende ejendomspriser, pres på statsfinanserne og finanssektoren. Den estiske økonomi skrumpede med godt 9 procent ved slutningen af 2008, og ventes at være nede på minus 12 procent for året 2009.

Estiske økonomer peger dog på, at landet systematisk klarer sig noget bedre end de to sydlige baltiske naboer med hensyn til stabilisering og genopretning af økonomien. En indikation af dette var, at Estland deltager som donor i den IMF-lånepakke, som blev ydet Letland i december 2008. Svenske og danske banker sidder på ca. 95 procent af den estiske banksektor. Estland er derfor meget afhængig af disse bankers muligheder for at tilføre ny kapital til finansmarkedet.

\section{Estisk udenrigspolitik}

\section{Estland blev optaget i NATO den} 29. marts $2004 \mathrm{og}$ blev medlem af EU den 1. maj 2004. Ved en forudgående folkeafstemning den 14. september 2003 stemte 68 procent for
EU-medlemskab. Estlands klart vestlige orientering og tidlige opnåelse af økonomisk vækst betød, at den vestlige verden gav landet forrang ved optagelsesforhandlingerne.

Regeringen fastholder kursen på det udenrigs- og sikkerhedspolitiske område: De overordnede prioriteter er fortsat EU og NATO, konsolidering af de gode relationer til USA samt en konsekvent politik over for Rusland og støtte til konkrete tiltag med henblik på udvikling af de estisk-russiske relationer. Estland er en varm fortaler for EU's fortsatte udvidelse og giver en hånd med, da Georgien, Ukraine og Moldova er hovedmodtagere af estisk bistand.

Der er fortsat store problemer med forholdet til Rusland. Estland og Rusland underskrev i maj 2005 en grænseaftale, som efterfølgende blev ratificeret af det estiske parlament. Kort efter den estiske ratifikation trak Rusland imidlertid sin undertegnelse tilbage, fordi man i den estiske ratifikationslov havde indsat en henvisning til Tartu-fredsaftalen i 1920. En henvisning, som russerne hævdede åbnede mulighed for estiske territorialkrav mod Rusland.

Forholdet blev forværret i foråret 2007 som følge af den estiske regerings beslutning om at flytte et politisk kontroversielt mindesmærke for faldne sovjetiske soldater under Anden Verdenskrig (Bronzesoldaten) fra Tallinns centrum. Efter en lang kontrovers, som var nær ved at sprænge regeringskoalitionen, blev 
statuen flyttet som planlagt til udkanten af byen, hvorefter sagen døde hen.

Der er nu tegn på en vis afspænding. Man har genoptaget politiske konsultationer på højt niveau og indledt et mere konstruktivt samarbejde mellem embedsmænd.

Estland har de senere år deltaget aktivt i en række internationale militære operationer. Estiske soldater deltager i NATO-styrken i Afghanistan samt i fredsbevarende missioner i Kosovo og Bosnien-Hercegovina

\section{Letlands indenrigspolitik}

Statsoverhoved er en præsident, som vælges af parlamentet. Præsidentvalg finder sted hvert fjerde år. Den nuværende præsident, kirurgen Valdis Zatlers, afløste Vaira Vike-Freiberga den 8 . juli 2007. Få har som hun evnet at sætte Letland på verdenskortet. Med sin canadiske akademiske baggrund, sin klare fornemmelse af den retning, Letland burde tage, og sin stærke vilje til at kommunikere de værdier, hun stod for, også når det gjorde ondt i det lokale politiske miljø, efterlod VikeFreiberga et stort tomrum, da hun gik af. Hendes efterfølgers stil er mindre iøjnefaldende, og ved begyndelsen af Zatlers præsidentperiode så det ud som om, man havde opnået politikernes drøm - en følgagtig præsident. Senere forløb har dog vist, at Zatlers følger sit kald og søger at udfylde sin rolle som stats- overhoved uden at give efter for politisk og økonomisk pression.

Præsidentens opgaver er hovedsageligt formelle, men i valgsituationer holder præsidenten 'dronningerunder' og er øverste chef for Letlands væbnede styrker og formand for det Nationale Sikkerhedsråd. I sin embedstid gjorde VikeFreiberga en indsats for at skabe en klarere defineret politisk rolle for embedet. Efterfølgeren Zatlers har hidtil ikke gjort meget ud af formaliteterne, men søger ganske modigt at vise politisk lederskab i en situation, hvor den siddende regering er handlingslammet.

Letlands forfatning daterer tilbage til det uafhængige Letland i perioden fra 1920 til Anden Verdenskrigs udbrud. Den er inspireret af den tyske Weimarforfatning og giver parlamentet større magt i tredelingen end normalt er i moderne forfatninger. Dette mindsker tilsvarende den lettiske regerings handlemuligheder og fører til hyppige politiske kriser og regeringsskift. I de 16 år mellem det første valg (1993) efter selvstændigheden og 2009 har Letland haft 14 regeringer. Mens dette skrives er der udsigt til, at nr. 15 kommer til inden længe.

Parlamentet (Saeima) består af 100 medlemmer, som vælges ved direkte valg hvert fjerde år. Det seneste parlamentsvalg blev afholdt i oktober 2006. Letlands tredje regering i løbet af denne valgperiode tiltrådte i marts 2009. Den ledes af premi- 
erminister Valdis Dombrovskis fra partiet Ny Tid. Foruden dette parti består regeringskoalitionen af fire andre centrum-højre partier: Borgerligt Forbund, Folkepartiet (Tautas Parti), Forbundet af Grønne og Landmænd samt Fædreland og Frihed. Oppositionens tre mindre partier mønstrer tilsammen kun 29 stemmer.

Letlands nyere historie viser, at regeringer udelukkende bæres af variationer af centrum-højre koalitioner. Personerne veksler, men partierne forbliver de samme. Dette forklares med, at enhver antydning af socialisme efter små 50 år i USSR bliver afvist af vælgerne. Dette forhindrer dog ikke, at vælgerbefolkningen i enkeltspørgsmål tilkendegiver venstreorienterede holdninger. "Vi tænker til venstre, men stemmer til højre", lyder folkeviddet. Der har endnu ikke vist sig plads for et center-center parti, selvom det ville styrke den politiske stabilitet.

Lettiske politiske partier har hidtil været løse formationer omkring enkeltpersoner. De savner folkelig forankring og mangler det fornødne til at skabe levedygtige organisationer - folk og penge. Ved 2006-valget var der dog tegn på øget professionalisering. Måske 2010-valget vil forstærke den tendens.

Der er en vis lettisk ømskindethed over for kritisk observation udefra, særlig på området menneskerettigheder. Det kom - igen - til udtryk i sommer, hvor Amnesty Internatio- nal offentliggjorde en rapport om den globale situation for menneskerettigheder. Det korte afsnit om Letland er kritisk, især med hensyn til behandlingen af det russiske mindretal, som er forholdt en række politiske rettigheder. Det kostede for år tilbage professor Ole Espersen hans genvalg til posten som Østersøområdets kommissær for menneskerettigheder, at også han pegede på diskrimination af det russiske mindretal i Letland. Organer som FN, Europarådet og EU har gennem årene regelmæssigt påpeget det samme, uden at kritikken er accepteret af Letland.

I den lettiske selvforståelse skyldes den 'forudindtagne' holdning mod Letland, at kritikerne ikke erkender den historiske baggrund og overser, at russerne befinder sig i Letland som resultat af den sovjetiske besættelse. Det siges ikke, men meningen er klar, at de politiske menneskerettigheder fortrinsvis gælder for 'de rigtige'. Denne tankegang trives især, men ikke bare på den nationalistiske højrefløj.

Der er dog også andre holdninger blandt eliten. Præsident Zatlers bad i sommer den lettiske ombudsmand, Romans Apsitis, om at give en vurdering af Amnesty-rapporten. Ombudsmandens svar foreligger nu og er offentliggjort. Apsitis foreslår en gennemgribende revision af de såkaldte ikke-statsborgeres rettigheder. Han påpeger, at det i stigende grad forekommer forkert, at borgere fra an- 
dre EU-lande har rettigheder i Letland, som forholdes russerne

\section{Økonomi i dyb krise}

Den lettiske økonomi er i dyb krise. Efter tre år med tocifrede vækstrater vendte billedet i 2008. I fjerde kvartal af 2008 faldt BNP med 10,4 procent sammenlignet med samme periode året før. Samlet set er BNP faldet med 4,6 procent i 2008, og der forventes BNP-fald på op til 20 procent $\mathrm{i}$ 2009. Underskuddet på betalingsbalancen blev i tredje kvartal af 2008 opgjort til 12,6 procent af BNP. Pr. 1. oktober 2008 udgjorde udlandsgælden 135 procent af BNP. Arbejdsløsheden var på ca. 11,1 procent medio april 2009, men med store regionale forskelle. Det vurderes, at tallet vil stige til knap 13 procent i løbet af 2009. Den lettiske valuta er bundet til euroen, og Letland er optaget i EU's valutamekanisme ERM II.

Den høje vækst i boom-perioden blev primært drevet af indenlandsk forbrug baseret på belåning af hurtigt voksende friværdier i fast ejendom samt høje lønstigninger, der ikke blev modsvaret af tilsvarende stigning i produktiviteten.

Grundet de massive økonomiske problemer har Letland indgået aftale med IMF, Europa-Kommissionen m.fl. om lånegarantier på 7,5 mia. Regeringen skal som led i aftalen begrænse det offentlige underskud kraftigt. Der foretages nu kraftige nedskæringer i centraladmini- strationen, måske op til 40 procent, og de offentlige lønninger er allerede beskåret med 15-20 procent. Skoler og hospitaler lukkes, og de ansatte står arbejdsløse. Indkomstskatten er sænket en anelse, men til gengæld er moms og specialafgifter hævet markant. Der er endnu kun taget få initiativer til støtte for erhvervslivet, herunder eksportsektorerne. Hvis den igangværende krise varer ved, vil den lettiske økonomi hurtigt udrydde boomtidens økonomiske fremgang og sætte landet tilbage til stagnationen før 2004.

\section{Lettisk udenrigspolitik}

Letland prioriterer i særlig grad det transatlantiske samarbejde, herunder medlemskabet af NATO og det bilaterale forhold til USA. EU og europæisk integration står ligeledes højt på dagsordenen. Letland kom med i EU-optagelsesrunden i marts 2004 og underskrev Lissabon-traktaten den 13. december 2007. Letland optoges i Schengen-samarbejdet i december 2007.

Forholdet til Rusland spiller en vigtig rolle i Letlands udenrigspolitik. Frem til Georgien-konflikten i august 2008 gik forholdet i retning af pragmatisk stabilisering og samarbejde. Der blev gjort væsentlige bilaterale fremskridt med undertegnelsen af en fælles grænseaftale og der arbejdes på indgåelse af flere aftaler om bl.a. dobbeltbeskatning og investeringsbeskyttelse. 
Men Georgien-konflikten styrkede den historisk betingede frygt for Rusland og førte til skarp kritik af Rusland fra regeringens side. Letland støtter EU's linje i konflikten, men lægger især vægt på, at EU og NATO-landene står fast og samlet over for Rusland. Rusland har ved flere lejligheder kritiseret Letlands behandling af det store russiske mindretal i landet.

Regionalt ønsker Letland at bidrage aktivt til EU's naboskabspolitik, herunder det $\emptyset$ stlige Partnerskab - blandt andet ved at dele Letlands egne erfaringer med reformer og integration i EU og NATO med nye partnerskabslande. Letland prioriterer Østersøsamarbejdet og det nordisk-baltiske samarbejde højt og har siden 1991 været medlem af OSCE. I september 2004 ansøgte Letland om medlemskab af OECD.

\section{Litauens indenrigspolitik}

Litauen er et velfungerende parlamentarisk demokrati med fri presse og uafhængige domstole. Det 141 sæder store parlament (Selmas) vælges hvert fjerde år. Samtlige parlaments- og præsidentvalg siden 1992 har været afholdt i overensstemmelse med internationale normer for frie og retfærdige valg. Præsidenten vælges direkte for en 5-årig periode, og har bl.a. kompetencer på det udenrigspolitiske område. Præsidenten udnævner statsministeren, der efter godkendelse i parla- mentet sammensæetter sin regering.

Ved det seneste præsidentvalg $\mathrm{i}$ maj 2009 vandt EU's tidligere budgetkommissær Dalia Grybauskaite overbevisende med en stemmeandel på 68 procent ved et valg, hvor 52 procent af befolkningen stemte. Grybauskaite tiltrådte som præsident den 12. juli 2009. Hun efterfulgte den patriarkalske Valdis Adamkus, som i sin præsidentperiode gjorde en stor indsats for at orientere Litauen mod vestlige holdninger og alliancer, samtidig med at han med held optrådte som opmand i politiske kriser i Ukraine.

Det seneste parlamentsvalg afholdtes i oktober 2008. Ved valget blev det Konservative Parti under ledelse af Andrius Kubilius den store vinder med 45 ud af de 141 pladser i Seimas. Kubilius var hurtig til at etablere en politisk koalition bestående af hans eget konservative parti, to små liberale partier og det nydannede parti Litauens Genopstandelse. Den nye centrum-højre regering blev godkendt den 9 . december 2008 og har med tilslutning fra to løsgængere 82 ud af parlamentets 141 pladser.

Regeringens første store opgave blev at forsøge at mindske effekterne af den økonomiske krise, som i sidste halvår af 2008 også ramte Litauen. Regeringen barslede derfor hurtigt med en økonomisk kriseplan, som skulle reducere underskuddet på betalingsbalancen og søge balance på de offentlige finan- 
ser. Planen indeholdt en skattereform med forøgelse af virksomhedsskatten fra 16 til 20 procent, sænkning af personskatten fra 24 til 21 procent, forøgelse af momsen fra 18 til 19 procent samt ophævelse af de fleste momslettelser.

Planen vakte stor utilfredshed både i medierne og i befolkningen, som forventer, at dens gennemførelse vil vende den tunge ende nedad. Dette markeredes i januar 2009 ved en demonstration med ca. 7.000 deltagere foran parlamentet.

I lyset af den økonomiske krises fortsatte uddybning har regeringen imidlertid varslet yderligere stramninger.

\section{Litauens udenrigspolitik}

Med optagelsen i EU og NATO i foråret 2004 virkeliggjorde Litauen de to vigtigste udenrigspolitiske målsætninger efter uafhængigheden i 1991- fuld integration i NATOs strukturer og optagelse i EU. Litauerne har været særligt effektive til at udnytte pengene fra EU's strukturfonde. Da landet i december 2007 blev optaget i Schengensamarbejdet, passerede det endnu en milepæl imod europæisk integration.

I marts 2008 underskrev Litauen og USA et memorandum, som er første skridt på vejen mod visumfrihed mellem de to lande.

Litauen har generelt et godt forhold til nabolandene og støtter prodemokratiske kræfter i Ukraine,
Hviderusland og landene i det sydlige Kaukasus. Integration af Georgien og Ukraine i NATO-samarbejdet er højt prioriteret.

Forholdet til Rusland er anspændt. På energiområdet stoppede Rusland i sommeren 2006 for råolieleverancerne til et stort litauisk olieraffinaderi via Druzhba-olierørledningen. De økonomiske konsekvenser for Litauen var betydelige. Rusland angav tekniske problemer som årsagen, men Litauen mente, at Rusland brugte sagen politisk i forbindelse med det polske selskab Orlens overtagelse af det litauiske raffinaderi Mazeiku Nafta, som russiske Gazprom var interesseret i.

Konflikten i Georgien i august 2008 og gaskonflikten imellem Rusland og Ukraine gav anledning til retoriske 'angreb' på Rusland. Men den ny udenrigsminister, Vygaudas Usaskas, synes dog at have en mere pragmatisk holdning til Rusland.

Energisikkerhed og udvidelse af antallet af energileverandører står højt på den politiske dagsorden. Man arbejder på en række projekter, der skal gøre Litauen mindre sårbar på energiområdet, hvoraf de vigtigste er: 1) Etablering - i samarbejde med de øvrige baltiske lande og Polen - af en ny, sikker atomreaktor til afløsning af Ignalinaværkets sidste reaktor, som skal lukkes senest ved udgangen af 2009. 2) Opkobling til det europæiske elnet via Polen. 3) El-ledning mellem Litauen og Sverige under Østersøen, samt 4) 
etablering af en terminal til modtagelse af flydende naturgas i Klaipeda.

Litauen deltager aktivt i internationale operationer og har mere end 200 soldater udsendt, heraf størstedelen i Afghanistan. Dertil kommer mindre bidrag til internationale missioner i Kosova, Bosnien og Georgien.

\section{Litauens økonomi}

Litauen havde i 2007 en økonomisk vækst i BNP på 8,9 procent og var dermed én af Europas hurtigst voksende økonomier. Under den økonomiske krise, som slog igennem i 2008, er denne vækst dog faldet til 3,0 procent i 2008. I februar 2002 skiftede Litauen fastkurstilknytning fra dollar til euro, og i juni 2004 indtrådte Litauen i EU's valutakursmekanisme, ERM II. Landet var tæt på at blive optaget i EURO-zonen pr. 1. januar 2007, men måtte vente, fordi det med en beskeden margin ikke overholdt EU's krav på inflationsområdet. Regeringens målsætning er fortsat at introducere euroen hurtigst muligt.

Fastkurspolitikken og den stramme pengepolitik medførte, at inflationen i Litauen før 2007 lå på et meget lavt niveau. Den kraftige økonomiske vækst, det stærkt stigende privatforbrug og de stigende energipriser førte til, at den årlige inflation i 2008 steg til 8,5 procent. For 2009 forventes en ca. 5 procent inflation.
Litauens arbejdsstyrke er veluddannet. Alligevel er arbejdsløsheden, der ved udgangen af 2008 var på 5,4 procent, i første kvartal af 2009 steget til 11,9 procent. Emigration af litauisk arbejdskraft, der tager til Vesteuropa og USA lokket af højere lønninger, påvirkede indtil 2008 den hjemlige arbejdsløshed i nedadgående retning, og har været med til at presse lønningerne opad. Men denne udvikling vendte i sidste halvdel af 2008, hvor flere og flere eksillitauere begyndte at vende hjem.

I maj 2009 forventede Litauens Nationalbank, at BNP reduceres med 15,6 procent i 2009 og med yderligere 4,5 procent i 2010 , ligesom det private forbrug og investeringerne forventes at falde markant. Finansministeriets beregninger forudser et fald i BNP på 18,2 procent i 2009.

\section{Fremtidsudsigterne}

Landeportrætterne giver et groft billede af den forventede økonomiske tilbagegang i 2009 Men tallene siger jo kun noget om en del af følgerne. Det fulde billede afhænger af det enkelte lands økonomiske og demografiske struktur. $\mathrm{Og}$ af den politiske vilje og formåen.

Perioden fra uafhængighed til begyndelsen af 2000-tallet var en barsk oplevelse for de baltiske befolkninger. Der blev brug for den nøjsomhed og stædighed, som sovjettiden havde gjort til vane. Men langsomt - 
i takt med den økonomiske vækst indfandt forbrugersamfundet sig. Og efter en kort overgang var de gamle holdninger afløst af lifestyle, nye biler og boliger - alt kreditfinansieret.

Med de fem fede år som udgangspunkt bliver det vanskeligt at rebe ind. Det vil kræve betydeligt mod hos politikere i de baltiske republikker at sige nej, og i betragtning af de ansvarliges frygt for at træffe upopulære beslutninger, kan det frygtes at der ikke bliver rebet i tide.

Dette gælder især i Letland, hvor flere på hinanden følgende regeringer har været totalt handlingslammede. Den siddende statsminister, Valdis Dombrovskis, ser i øjeblikket sin vigtigste koalitionspartner på vej til at springe fra, fordi man ikke vil støtte øget beskatning. Det bliver et problem for landet, idet fortsat EU-finansstøtte er betinget af alvorlige økonomiske tiltag for at bringe orden i statsfinanserne.

Flere af de højresnoede lettiske partiledere lever med en interessekonflikt, idet de samtidig er aktive i private finanstransaktioner. Det gør det næsten umuligt at komme til enighed om effektive økonomiske forholdsregler, som ikke generer den ene eller den anden.

I den sidste del af sin præsidentperiode tog Vaira Vike-Freiberga flere gang bladet fra munden og betegnede den lettiske politiske elite som selvbetjenende. "Man drager først sin personlige fordel, og landets interesser kommer i anden række", sagde hun. Den formidable præsident har videregivet embedet, men den politiske elite sidder stadig tilbage.

Som skildret er forventningerne for 2009 for de tre lande en økonomisk tilbagegang i størrelsesordenen: Estland 12 procent, Letland 20 procent og Litauen 18 procent.

Estland og Litauen synes bedre udstyret med politisk stabilitet og handlekraft. Esternes begavede og dynamiske præsident Toomas $\mathrm{H}$. Ilves har krisebekæmpelse højest på dagsordenen. Litauens nytiltrådte præsident, Dalia Grybauskaite, kommer fra opgaven som ansvarlig for EU's budget og vil uden al tvivl bruge sine noget større beføjelser på at søge at trække landet igennem. Letlands ustabile situation er opridset ovenfor.

Udfra disse betragtninger ser det ud til, at esterne og litauerne kan håbe på lys for enden af tunnellen. Hvordan Letland vil klare sig igennemer et helt åbent spørgsmål.

Ib Alken, cand. jur., var i mere end 30 år ansat $i$ den danske udenrigstjeneste. Han bor og arbejder nu i Letland.

\section{Udvalgte kilder:}

Artis Pabriks og Aldis Purs "Latvia the challenges of change" (Routledge 2000) David Kirby "The Baltic World 1772-1993

(Longman 1995)

www.ambtallinn.um.dk

www.ambriga.um.dk www.ambvilnus.um.dk 